\title{
Cannabinoid Receptor Antagonists Counteract Sensorimotor Gating Deficits in the Phencyclidine Model of Psychosis
}

\author{
Martina Ballmaier*, , Marco Bortolato ${ }^{2,3}$, Cristina Rizzetti ${ }^{4}$, Michele Zoli ${ }^{5}$, GianLuigi Gessa ${ }^{3,6}$, \\ Andreas Heinz ${ }^{1,6}$ and PierFranco Spano ${ }^{4,6}$ \\ 'Department of Psychiatry and Psychotherapy, Charité University Medicine, Campus Mitte, Berlin, Germany; '2Department of Pharmacology, \\ University of California, Irvine, USA; ${ }^{3}$ Department of Neuroscience, Bernard B Brodie, University of Cagliari, Cagliari, Italy; ${ }^{4}$ Department of \\ Biomedical Sciences and Biotechnologies, Brescia University Medical School, Brescia, Italy; ${ }^{5}$ Department of Biomedical Sciences, University \\ of Modena and Reggio Emilia, Modena, Italy
}

\begin{abstract}
Clinical and laboratory findings suggest that cannabinoids and their receptors are implicated in schizophrenia. The role of cannabinoids in schizophrenia remains however poorly understood, as data are often contradictory. The primary aim of this study was to investigate whether the cannabinoid CBI receptor antagonists rimonabant and AM25I are able to reverse deficits of sensorimotor gating induced by phencyclidine and to mimic the 'atypical' antipsychotic profile of clozapine. The prepulse inhibition (PPI) of the startle reflex was used to measure deficits of sensorimotor gating. PPI-disruptive effects of phencyclidine and their antagonism by rimonabant, AM25I, and clozapine were studied in rats. The effects of rimonabant were carefully examined taking into account dose ranges, vehicle, and route of administration. We also examined the ability of rimonabant to reduce the PPI-disruptive effects of dizocilpine and apomorphine. Rimonabant as well as AM25 I significantly counteracted the phencyclidine-disruptive model of PPI, comparable to the restoring effect of clozapine; no augmentation effect was observed with rimonabant and clozapine as cotreatment. Rimonabant also significantly attenuated the PPI disruptive effects of dizocilpine and apomorphine. Taken together, our results indicate that CBI receptor antagonists do produce 'atypical' antipsychotic profile mimicking that of clozapine in the phencyclidine disruption of sensorimotor gating. Our findings further suggest that $\mathrm{CBI}$ receptor antagonism may be involved in restoring disturbed interactions between the activity of the endocannabinoid system and glutamate neurotransmitter system implied in schizophrenia.

Neuropsychopharmacology (2007) 32, 2098-2 107; doi: I 0. I 038/sj.npp. I 30 I344; published online I4 February 2007
\end{abstract}

Keywords: sensorimotor gating; prepulse inhibition; phencyclidine; schizophrenia; cannabinoid antagonists; rimonabant

\section{INTRODUCTION}

Cannabis sativa is one of the most frequently abused substances among schizophrenic patients (Jablensky et al, 1992). Although some researchers have interpreted this phenomenon to hypothesize cannabis consumption as a method of self-therapy for counterbalancing negative symptoms of schizophrenia or side effects of antipsychotic treatment (Dixon et al, 1991; Krystal et al, 1999), recent meta-analyses of epidemiologic studies have concluded that cannabis use is a risk factor or contributory cause of developing psychosis (Hall, 2006; Henquet et al, 2005; Semple et al, 2005). Indeed, the impact of cannabis in

*Correspondence: Dr M Ballmaier, Department of Psychiatry and Psychotherapy, Charité University Medicine, Campus Mitte, Schumannstrasse 20/21, I0117 Berlin, Germany, Tel: + 49 (030) 450 5l700।, Fax: + 49 (030) 450 51792I,

E-mail: martina.ballmaier@charite.de

${ }^{6}$ These authors contributed equally to this work.

Received 16 October 2006; revised 27 December 2006; accepted 28 December 2006 schizophrenia may greatly vary across subjects, plausibly depending on factors such as individual susceptibility to cannabinoids (Hall, 1998), as well as specific neurobiological differences in cannabinoid circuitry among different diagnostic clusters (Ujike et al, 2002). Nevertheless, several lines of evidence suggest the involvement of cannabinoid $\mathrm{CB}_{1}$ receptors and their endogenous ligands, anandamide and 2-arachidonylglycerol (2-AG), in the pathophysiology of schizophrenia.

$\mathrm{CB}_{1}$ receptors are mainly distributed in areas of the human brain implicated in schizophrenia, including prefrontal cortex, anterior cingulate cortex, basal ganglia, and hippocampus (Rinaldi-Carmona et al, 1996); of note, post-mortem studies have shown increased $C_{1}$ receptor densities in the prefrontal and anterior cingulate cortex of schizophrenics as compared with the normal controls (Dean et al, 2001; Ujike and Morita, 2004; Zavitsanou et al, 2004). Furthermore, animal studies indicate that cannabinoid $\mathrm{CB}_{1}$ receptors interact with the main neurotransmitter systems implied in the pathophysiology of schizophrenia, such as dopamine and glutamate (Heinz et al, 2003; van der Stelt and Di Marzo, 2003). 
Emerging evidence seems to point to a possible antipsychotic-like effect of anandamide, as the selective inhibition of its degradation reduces the effect of D2 receptor activation on several behavioral parameters (Beltramo et al, 2000; Tzavara et al, 2006). Moreover, anandamide levels in cortico-spinal fluid of antipsychoticnaïve schizophrenic patients are markedly elevated and inversely correlated with psychopathological symptoms (Giuffrida et al, 2004).

Conversely, 2-AG might contribute to trigger or exacerbate psychotic symptoms by inhibiting glutamate release and signaling in several brain areas through activation of presynaptic cannabinoid $\mathrm{CB}_{1}$ receptors (Domenici et al, 2006; Heresco-Levy, 2005; Piomelli, 2003).

In light of this multifaceted background, it is of great interest to investigate the effects of $\mathrm{CB}_{1}$ antagonists, in order to assess the role of this receptor in the regulation of the neurobiological mechanisms underlying psychotic phenomena.

One important endophenotype of schizophrenia is the impairment of sensorimotor gating (Gotesman and Gold, 2003). This preattentional function has been defined as a process by which an organism filters extraneous information from external and internal milieu, and its dysfunction is a common feature across the schizophrenia spectrum (Braff et al, 2001). The most reliable paradigm for measuring abnormalities of sensorimotor gating is the prepulse inhibition (PPI) of the acoustic startle reflex. Deficits of PPI are seen across the entire spectrum of psychotic disorders (Braff et al, 1978, 2001; McGhie and Chapman, 1961). Notably, PPI can be assessed across species using near-identical stimulus parameters (Swerdlow and Geyer, 1998), and changes in this paradigm have been used to predict antipsychotic efficacy (Swerdlow et al, 2002). All antipsychotics without distinction between 'typical' and 'atypical' profiles reverse PPI in rats treated with dopamine agonists, such as apomorphine (Martinez et al, 2002; Swerdlow and Geyer, 1993, 1998). On the contrary, PPI disruption induced by $N$-methyl-D-aspartate (NMDA) receptor antagonists, such as phencyclidine, is preferentially reversed by clozapine and other 'atypical' antipsychotic agents (Bakshi and Geyer, 1995; Bakshi et al, 1994; Geyer and Ellenbroek, 2003; Keith et al, 1991; Swerdlow et al, 1996).

The primary goal of this study was to examine whether $\mathrm{CB} 1$ receptor blockade by two well-validated $\mathrm{CB}_{1}$ receptor antagonists, such as rimonabant and the even more selective AM251 (Hajos and Freund, 2002; Mato et al, 2002) can reverse the gating deficits in the PPI-disruptive model of phencyclidine and parallel the restoring effects of clozapine in this model.

To date, a number of observations concerning the effects of rimonabant on psychosis-relevant behaviors in animals have yielded contrasting results. In particular, in one study rimonabant did not reverse the PPI-disruptive effects of apomorphine, amphetamine, or dizocilpine (Martin et al, 2003). However, the phencyclidine animal model, which produces the most robust PPI deficits (Geyer and Ellenbroek, 2003) and has excellent face validity for core psychotic symptoms (Moghaddam and Jackson, 2003), was not used in these studies. In the present investigation, particular attention was given to vehicle used, route of administration and dose ranges of rimonabant in the phencyclidine paradigm. In addition, we re-examined the effects of rimonabant on PPI following disruptions by dizocilpine and apomorphine.

\section{MATERIALS AND METHODS}

\section{Animals}

A total of 355 male Sprague-Dawley rats (Harlan, Italy) weighing $250-350 \mathrm{~g}$ served as subjects in the present study. Rats were housed in groups of two in plastic cages under reversed 12-h light-dark cycle (lights on at 2000 and off at 0800). Methods for housing and all behavioral testing were performed according to the substantial literature of startle measures in rodents (Swerdlow et al, 2002). Food and water were available ad libitum, and each rat was handled individually within 3 days of arrival and daily thereafter. Throughout all experiments efforts were made to minimize animal suffering. Behavioral testing occurred between 0900 and 1500 (Swerdlow et al, 1996), unless otherwise indicated. All experimental procedures were approved by the local institutional Ethical Committee and carried out in strict accordance with the European Community guidelines for care and use of experimental animals (CEE NE86/609).

\section{Drugs and Chemicals}

The following drugs were used: phencyclidine hydrochloride $(1.25 \mathrm{mg} / \mathrm{kg}$, s.c. $)$; dizocilpine $(0.1 \mathrm{mg} / \mathrm{kg}$, s.c.); apomorphine $(0.25 \mathrm{mg} / \mathrm{kg}$ s.c. $)$; rimonabant $(0.75,1.5$, or $3.0 \mathrm{mg} / \mathrm{kg}$, s.c.); AM251 (1.4 or $1.8 \mathrm{mg} / \mathrm{kg}$, s.c.); clozapine $(7.5 \mathrm{mg} / \mathrm{kg}$ i.p.). Phencyclidine, dizocilpine, apomorphine, and clozapine were purchased from Sigma Aldrich, Italy. Rimonabant was obtained from the National Institute of Mental Health's Chemical Synthesis and Drug Supply Program. AM251 was purchased from Tocris, UK. Phencyclidine and dizocilpine were dissolved in $0.9 \%$ saline. Apomorphine was dissolved in saline with $0.1 \%$ ascorbic acid. Rimonabant and AM251 were dissolved in ethanol, Tween 80 , and $0.9 \%$ saline (ratio $1: 1: 18$ ). Ethanol final concentration was $3.75 \%$; this amount of ethanol does not produce any effect on PPI, as confirmed by the results of a preliminary study performed to compare saline with rimonabant or AM251 (data not shown). All drugs were administered in an injection volume of $1 \mathrm{ml} / \mathrm{kg}$. The doses of phencyclidine, dizocilpine, and apomorphine were chosen because they have been found previously to significantly disrupt PPI in rats (Bakshi et al, 1994; Geyer et al, 2001; Mansbach and Geyer, 1989; Zhang et al, 1999); the doses of rimonabant and AM251 were chosen on the grounds of a preliminary set of doseresponse experiments assessing their ability to reverse PPI disruption. All substances were administered at a convenient time interval before experimental testing, compatible with their pharmacokinetic properties, as shown in previous papers and in preliminary experiments, so as to elicit their effects during behavioral testing (Bakshi and Geyer, 1995; De Vries et al, 2001; Geyer et al, 2001; Swerdlow et al, 1996, 2002). All experiments were conducted in separate groups of drug-naive and experimentally naive rats. Each rat was only tested for PPI once, in one drug condition. 


\section{Behavioral Testing}

Startle experiments used two identical startle chambers (SRLAB system, San Diego Instruments, San Diego, CA) housed in a sound-attenuated room with a $60-\mathrm{dB}$ ambient noise level. Each chamber consisted of a Plexiglas cylinder $8.2 \mathrm{~cm}$ in diameter resting on a $12.5 \times 25.5 \mathrm{~cm}$ Plexiglas frame within a ventilated enclosure. The delivery of acoustic stimuli was controlled by the SR-LAB microcomputer and interface assembly, which also digitized, rectified, and recorded stabilimeter readings, with $100,1-\mathrm{ms}$ readings collected beginning at stimulus onset. Startle magnitude was defined as the average of the 100 readings. Acoustic stimuli and background noise were presented via a Radio Shack Supertweeter mounted $24 \mathrm{~cm}$ above the Plexiglas cylinder. Startle magnitude was detected and recorded as transduced cylinder movement via a piezoelectric device mounted below the Plexiglas stand. All sound levels within each chamber were calibrated regularly and found to remain constant over the test period (SR-LAB Startle Calibration System).

\section{Testing Procedures}

Three days before drug testing each rat was placed into the startle chamber with $70 \mathrm{~dB}$ background noise and $5 \mathrm{~min}$ later was exposed to 18 pulse-alone (a $40 \mathrm{~ms}, 120 \mathrm{~dB}$ noise burst) trials and six prepulse + pulse (a $20 \mathrm{~ms}, 82-12 \mathrm{~dB}$ over background-burst followed $100 \mathrm{~ms}$ later by the $120 \mathrm{~dB}$ burst) trials. The purpose of this initial session was to create equally matched treatment groups based on the mean startle magnitude data (from the pulse-alone trials) for each rat (Ballmaier et al, 2001, 2002; Swerdlow et al, 1996).

On testing days, approximately $1 \mathrm{~h}$ after arrival in the laboratory, rats were placed in a startle chamber (closed Plexiglas cylinder). Each test session was approximately $20 \mathrm{~min}$ long and consisted of $5 \mathrm{~min}$ of $70 \mathrm{~dB}$ background noise followed by several presentations in a pseudorandom order of five trial types: (1) pulse alone noise burst (a $40 \mathrm{~ms}$ $120 \mathrm{~dB}$ noise burst); (2) prepulse trials which consisted of 20 -ms noise bursts 3,6 , or $12 \mathrm{~dB}$ above $70 \mathrm{~dB}$ background noise followed $100 \mathrm{~ms}$ later by a $120 \mathrm{~dB}$ pulse; (3) no stimulus in which only the background noise was presented. The no stimulus trials were used to assess gross motor activity during the test session but were not included in the statistical analysis. There was a total number of 50 trials (12 pulse-alone trials, 10 each of the $3-, 6-$, or $12-\mathrm{dB}$ prepulse + pulse trials, eight no stimulus trials). In addition, five pulse alone trials, which were not included in the calculation of PPI values, were presented at the beginning and at the end of the test session to ensure a relatively stable level of startle reactivity for the remainder of the session. Prepulse intensities were chosen to span a range of relatively weak $(3 \mathrm{~dB})$ and intense $(12 \mathrm{~dB})$ stimuli. Intertrial intervals averaged $15 \mathrm{~s}$.

For experiments assessing the effects with rimonabant, saline or one of the doses of rimonabant $(0.75,1.5,3.0 \mathrm{mg} /$ $\mathrm{kg}$ s.c.) were administered as pretreatment. Rats were then treated as follows: saline or phencyclidine $20 \mathrm{~min}$ after pretreatment followed by other $10 \mathrm{~min}$ before being placed in the startle chamber for the test session; saline or dizocilpine $15 \mathrm{~min}$ after pretreatment followed by other
$15 \mathrm{~min}$ before being tested; saline or apomorphine $30 \mathrm{~min}$ after pretreatment and immediate transfer of the animal in the startle chamber for the test session. For experiments investigating the effects of AM251, rats were pretreated with saline or one of the doses of AM251 ( 1.4 or $1.8 \mathrm{mg} / \mathrm{kg} \mathrm{s.c.),}$ followed by saline, or phencyclidine, as stated above. In a series of experiments, clozapine was administered as a pretreatment $30 \mathrm{~min}$ before PPI testing. In the clozapine plus rimonabant experiment, rats were pretreated with vehicle or clozapine followed $10 \mathrm{~min}$ later by vehicle or rimonabant; after 20 min the rats received phencyclidine and 10 min later each rat was placed in the startle chamber for a test session.

\section{Data Analysis}

PPI data were analyzed with the general linear model univariate analysis of variance (ANOVA) using PPI values as dependent variable and pharmacological treatment and prepulse magnitude as fixed factors (statistical package, SPSS version 10). The prepulse magnitude was analyzed at all $3 \mathrm{~dB}$ levels. The amount of PPI was defined as the percent reduction in startle magnitude in the presence of the prepulse compared to the magnitude in the absence of the prepulse $(100-(100 \times$ magnitude on prepulse trial/magnitude on pulse trial). Startle magnitude was calculated as the average response to all of the pulse-alone trials. The initial and final five pulse-alone trials were not included in the analysis, in order to ensure the calculation of PPI over a more stable range of startle responses. Startle amplitude data were analyzed with one-way ANOVA. The Bonferroni test was used as a post hoc test for multiple comparisons with $p<0.05$ as threshold for significant difference.

\section{RESULTS}

\section{Effects of Pretreatment with Rimonabant on Phencyclidine-Induced Disruption of PPI and Startle Magnitude}

In the first series of experiments, we wanted to test whether the $\mathrm{CB}$ antagonist rimonabant affects the phencyclidineinduced deficit of PPI. As a preliminary experiment, we assessed possible effects on PPI of several doses $(0.75 \mathrm{mg} /$ $\mathrm{kg}, n=8,1.5 \mathrm{mg} / \mathrm{kg}, n=6,3.0 \mathrm{mg} / \mathrm{kg}, n=8$, s.c.; saline $n=5$ ) of rimonabant and found that this drug does not significantly alter either startle amplitude or PPI when administered alone at the doses tested (Figure 1a and $\mathrm{b}$ ).

Then, we tested three doses of rimonabant $(0.75,1.5$, or $3.0 \mathrm{mg} / \mathrm{kg}$ s.c., administered $30 \mathrm{~min}$ before PPI procedure) on phencyclidine $(1.25 \mathrm{mg} / \mathrm{kg}$, s.c., administered $10 \mathrm{~min}$ before PPI procedure) induced disruption of PPI (Figure 2a). Rats treated with phencyclidine showed a significant decrease in PPI with respect to saline-treated rats (all groups $n=5$ /group), (two-way ANOVA, Groups: $\mathrm{F}(4,60)=15.06 p<0.001$; Prepulse intensity: $\mathrm{F}(2,60)=$ $22.19 p<0.001$; Groups $\times$ Intensity: $\mathrm{F}(8,60)=0.26 \mathrm{NS}$; post hoc Bonferroni's test: phencyclidine vs sal $p<0.001)$ (Figure 2a). Pretreatment with rimonabant at all doses tested significantly counteracted phencyclidine-induced decrease in PPI (rimonabant0.75+ phencyclidine vs phencyclidine $p<0.001$, rimonabant $1.5+$ phencyclidine $v s$ 

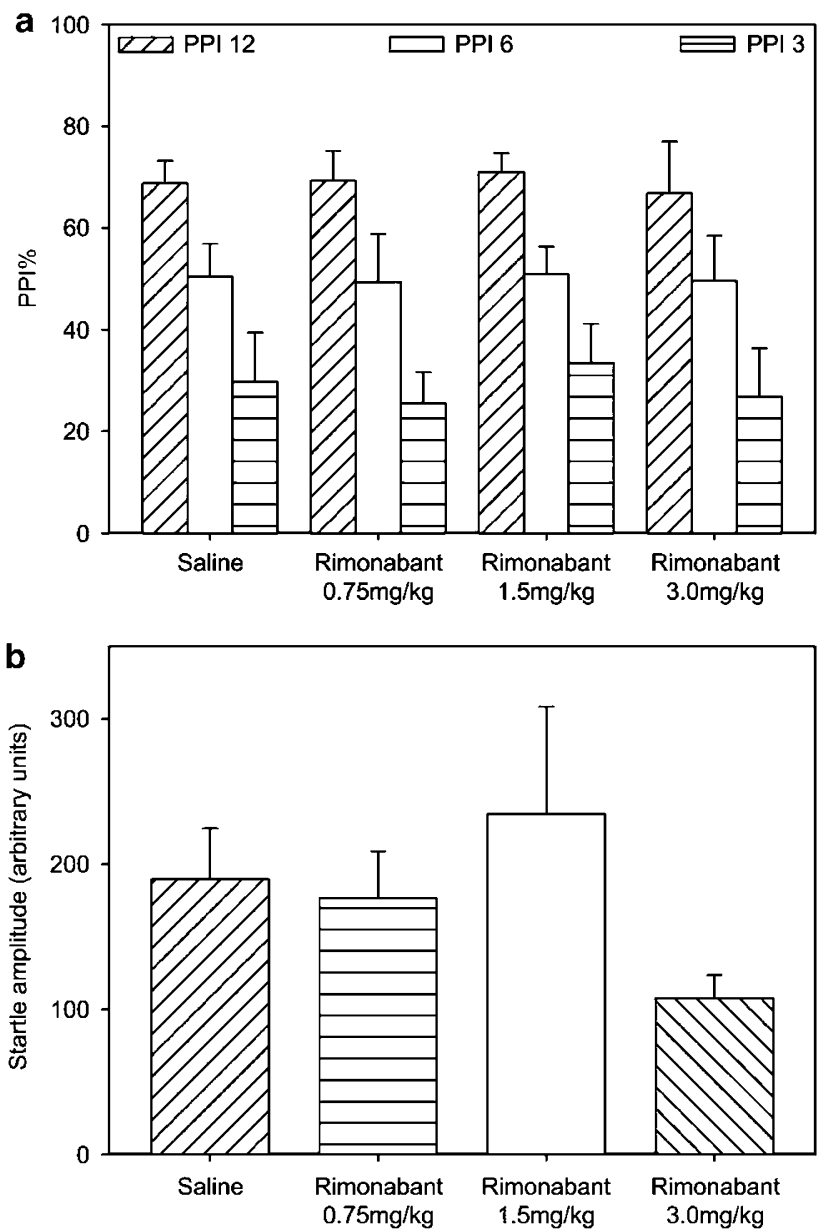

Figure I (a) Effects of rimonabant $(0.75-3.0 \mathrm{mg} / \mathrm{kg}$, s.c.) on PPI. (b) Effects of rimonabant $(0.75-3.0 \mathrm{mg} / \mathrm{kg}$, s.c.) on startle amplitude.

phencyclidine $p<0.001$, rimonabant $3.0+$ phencyclidine $v s$ phencyclidine $p=0.018$ ) (Figure 2a). No drug treatment significantly altered startle amplitude (Figure 2b). This finding was re-examined carrying out the behavioral testing between 1500 and 2100 with different groups of animals ( $n=5$ /group). The results (not shown) revealed the same level of significance as described above.

In order to confirm that the effects of rimonabant on phencyclidine-induced disruption of PPI are due to its activity on CB1 receptors, we repeated the experiment using AM251, a more selective CB1 receptor antagonist, at doses equivalent to the median effective dose, as determined in our studies of rimonabant. AM251 (1.4, $1.8 \mathrm{mg} / \mathrm{kg}$ s.c., administered $30 \mathrm{~min}$ before PPI procedure) significantly counteracted phencyclidine-induced disruption of PPI (all groups $n=5$ /group; two-way ANOVA, Groups: $\mathrm{F}(3,48)=$ $21.35 p<0.001$; Prepulse intensity: $\mathrm{F}(2,48)=65.60 p<0.001$; Groups $\times$ Intensity: $\mathrm{F}(6,48)=1.77$ NS; post hoc Bonferroni's test: phencyclidine $v s$ sal $p<0.001$, AM251 $1.4+$ phencyclidine $v s$ phencyclidine $p=0.003$, AM251 $1.8+$ phencyclidine $v s$ phencyclidine $p<0.001$, AM251 $1.4+$ phencyclidine $v s$ sal $p<0.001$, AM251 $1.8+$ phencyclidine $v s$ sal $p=0.079$ ) (Figure 3a). No drug treatment significantly affected startle amplitude (Figure $3 b$ ).
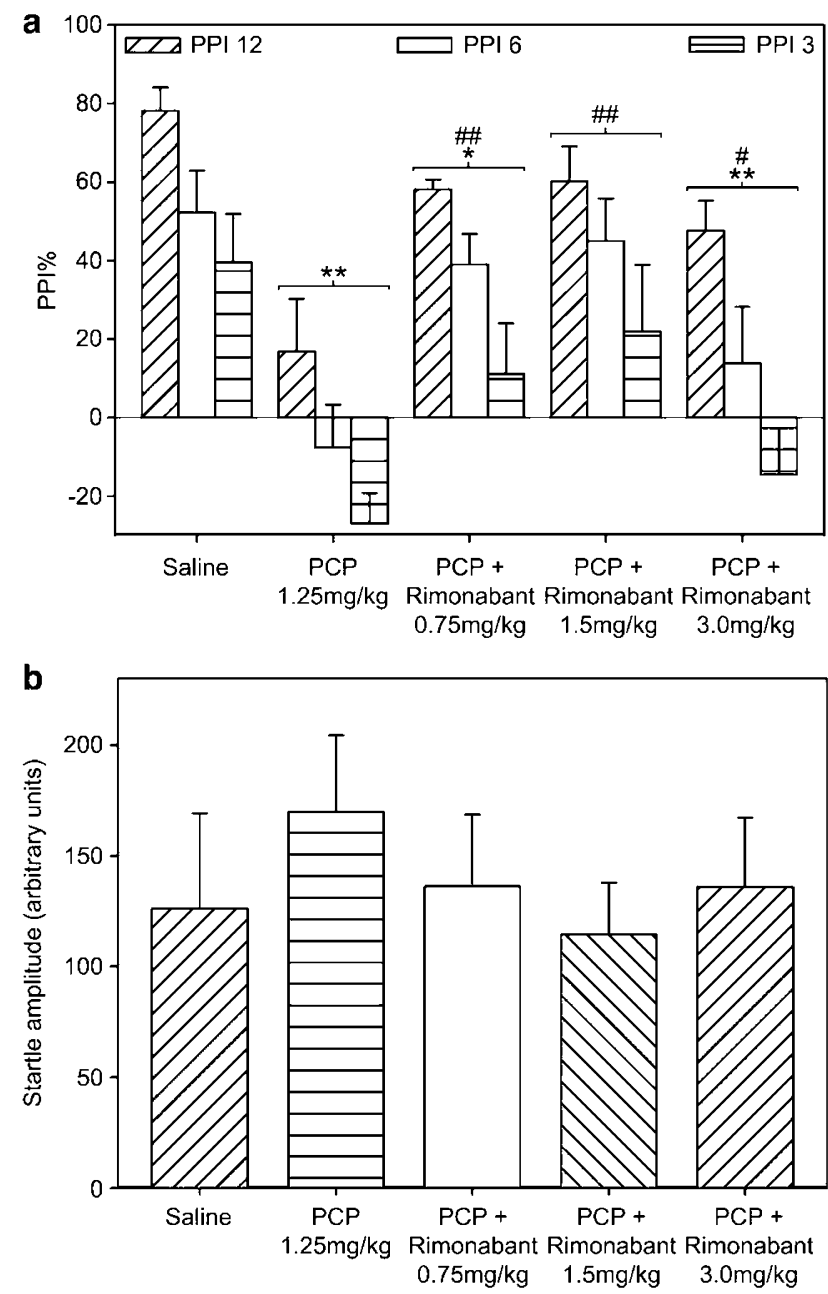

Figure 2 (a) Effects of rimonabant (0.75-3.0 mg/ $/ \mathrm{kg}$, s.c.) on disruption of PPI induced by phencyclidine ( $1.25 \mathrm{mg} / \mathrm{kg}$, s.c.). (b) Effects of rimonabant (0.75-3.0 mg $/ \mathrm{kg}$, s.c.) and/or phencyclidine (1.25 mg/ $/ \mathrm{kg}$, s.c.) on startle amplitude. PCP $=$ phencyclidine.

The effects of rimonabant on phencyclidine-induced disruption of PPI were compared with those of the atypical antipsychotic clozapine. Rimonabant $(1.5 \mathrm{mg} / \mathrm{kg}$ s.c., administered $30 \mathrm{~min}$ before PPI procedure) and clozapine ( $7.5 \mathrm{mg} / \mathrm{kg}$ i.p., administered $30 \mathrm{~min}$ before PPI procedure) treatments as well as rimonabant + clozapine cotreatment significantly counteracted phencyclidine effects on PPI (all groups $n=12$ /group; two-way ANOVA, Groups: $\mathrm{F}(4,165)=$ $27.64 \quad p<0.001$; Prepulse intensity: $F(2,165)=87.82$ $p<0.001$; Groups $\times$ Intensity: $\mathrm{F}(8,165)=1.78 \mathrm{NS}$; post hoc Bonferroni's test: phencyclidine $v s$ sal $p<0.001$, rimonabant + phencyclidine $v s$ phencyclidine $p<0.001$, clozapine + phencyclidine $v s$ phencyclidine $p<0.001$, rimonabant + clozapine + phencyclidine $v s$ phencyclidine $p<0.001)$ and were significantly different from saline treatment (rimonabant + phencyclidine $v s$ sal $p<0.001$, clozapine + phencyclidine $v s$ sal $p=0.034$, rimonabant + clozapine + phencyclidine $v s$ sal $p<0.001$ ) (Figure $4 \mathrm{a}$ ). However, there was no additive effect of rimonabant + clozapine pretreatment with respect to rimonabant or clozapine pretreatments alone (rimonabant + phencyclidine + clozapine $v s$ clozapine + phencyclidine or rimonabant + phencyclidine NS) 

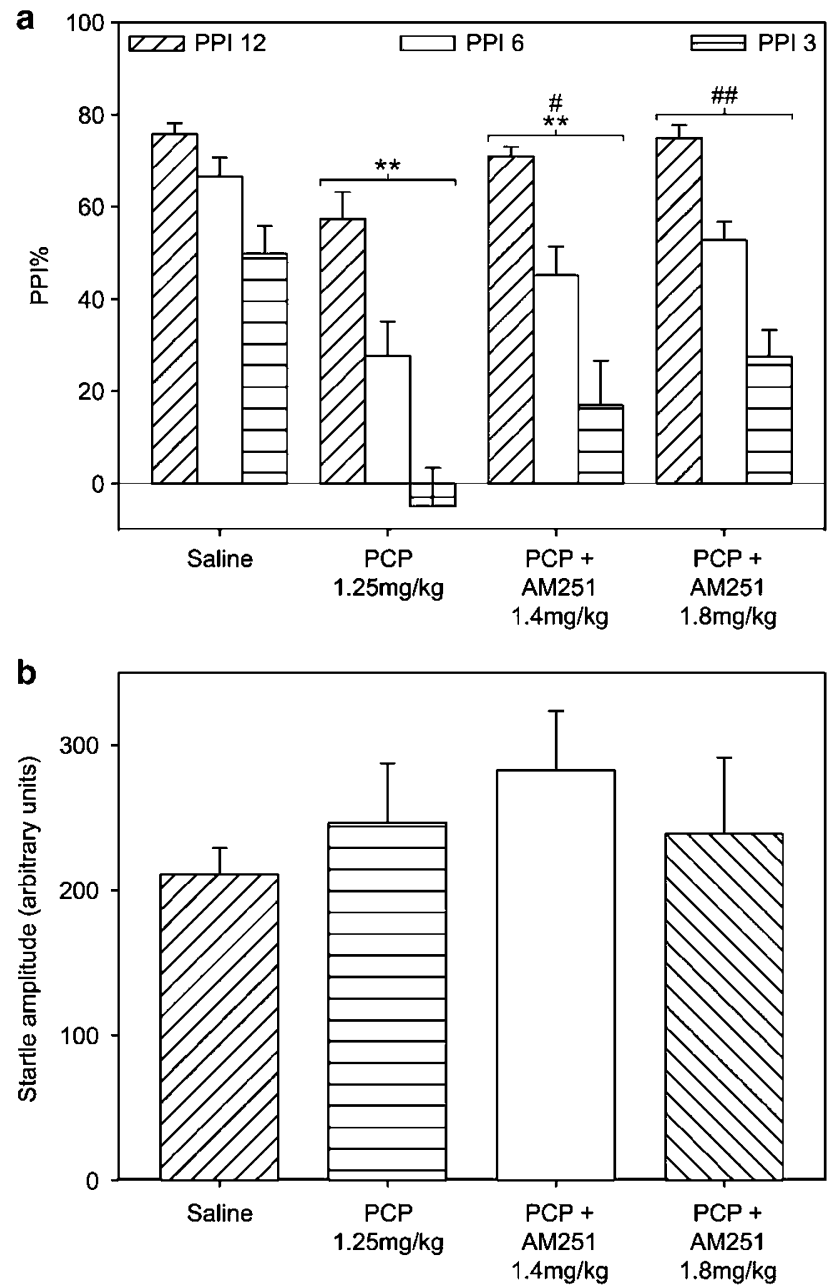

Figure 3 (a) Effects of AM25 I (I.4, $1.8 \mathrm{mg} / \mathrm{kg}$, s.c.) on disruption of PPI induced by phencyclidine ( $1.25 \mathrm{mg} / \mathrm{kg}$, s.c.), (b) Effects of AM25। (I.4, $1.8 \mathrm{mg} / \mathrm{kg}$, s.c.) and $/$ or phencyclidine ( $1.25 \mathrm{mg} / \mathrm{kg}$, s.c.) on startle amplitude. $\mathrm{PCP}=$ phencyclidine.

(Figure 4a). No drug treatment altered startle amplitude with respect to saline treatment (Figure $4 \mathrm{~b}$ ).

\section{Effects of Pretreatment with Rimonabant on Dizocilpine-Induced Disruption of PPI and Startle Magnitude}

In order to substantiate the results observed on phencyclidine in the PPI paradigm, we studied the effects of rimonabant pretreatment $(1.5 \mathrm{mg} / \mathrm{kg}$, s.c.) on PPI disruption induced by dizocilpine $(0.1 \mathrm{mg} / \mathrm{kg}$ s.c., administered $15 \mathrm{~min}$ before PPI procedure), another NMDA noncompetitive antagonist. As already shown, dizocilpine significantly decreased PPI with respect to saline treatment (all groups $n=16$ /group; two-way ANOVA, Groups: $\mathrm{F}(3,180)=110.08$ $p<0.001$; Prepulse intensity: $\mathrm{F}(2,180)=46.52 p<0.001$; Groups $\times$ Intensity: $\mathrm{F}(6,180)=2.01 \mathrm{NS}$; post hoc Bonferroni's test: dizocilpine $v s$ sal $p<0.001$ ) (Figure 5). Rimonabant did not alter PPI but significantly counteracted dizocilpine disruption of PPI (rimonabant $v s$ sal NS, rimonabant + dizocilpine $v s$ dizocilpine $p<0.001$, rimonabant + dizocilpine $v s$ sal $p<0.001$ ) (Figure 5). No drug treatment altered
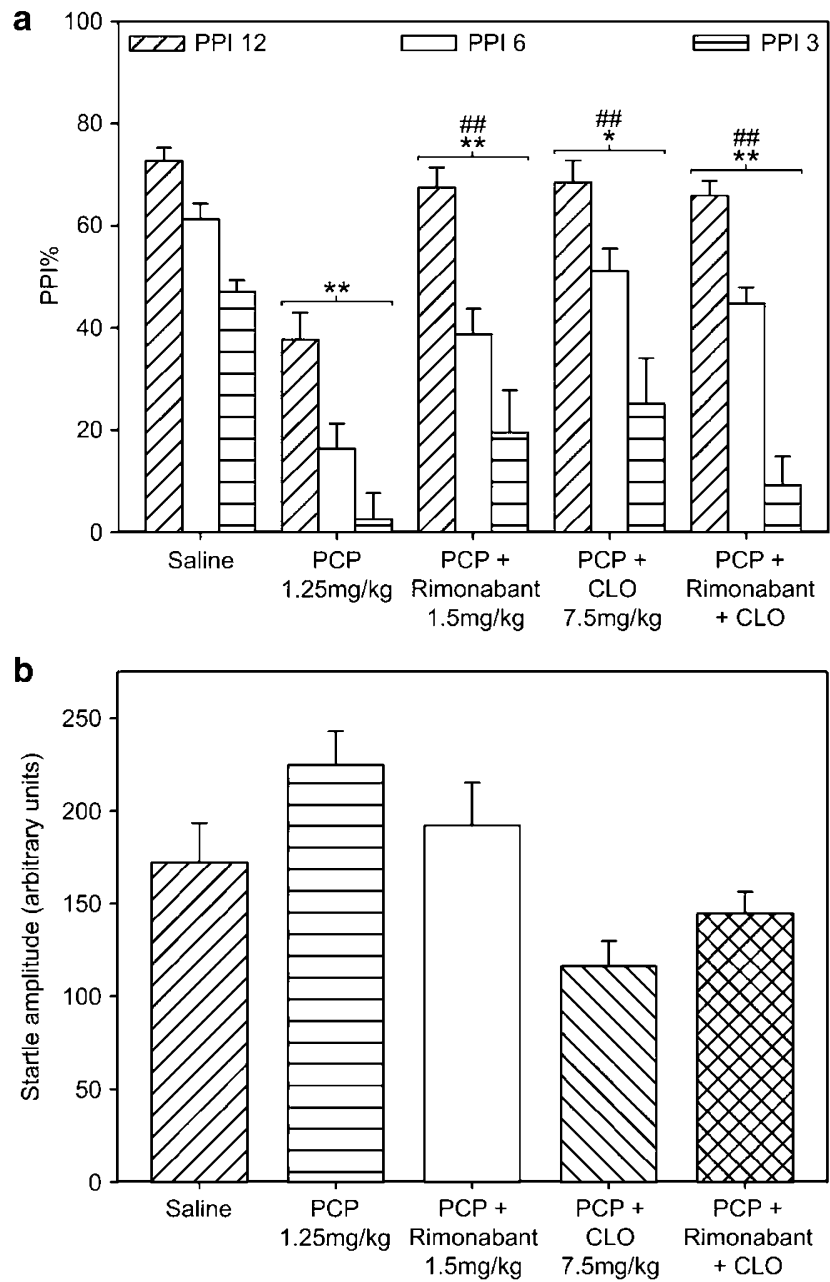

Figure 4 (a) Effects of rimonabant ( $1.5 \mathrm{mg} / \mathrm{kg}$, s.c.) or clozapine $(7.5 \mathrm{mg} /$ $\mathrm{kg}$, i.p.) on disruption of PPI induced by phencyclidine (1.25 mg/kg, s.c.). (b) Effects of rimonabant (1.5 mg/ $/ \mathrm{kg}$, s.c.) and/or phencyclidine (1.25 mg/kg, s.c.) and/or clozapine $(7.5 \mathrm{mg} / \mathrm{kg}$, i.p.) on startle amplitude. CLO= clozapine; $\mathrm{PCP}=$ phencyclidine.

startle amplitude with respect to saline treatment (not shown).

\section{Effects of Pretreatment with Rimonabant on Apomorphine-Induced Disruption of PPI and Startle Amplitude}

In a second series of experiments, we tested whether rimonabant $(1.5 \mathrm{mg} / \mathrm{kg}$, administered $30 \mathrm{~min}$ before PPI procedure) prevents PPI disruption induced by apomorphine $(0.25 \mathrm{mg} / \mathrm{kg}$ s.c., administered immediately before the PPI procedure), a nonselective dopaminergic agonist. Apomorphine significantly decreased PPI with respect to saline treatment (all groups $n=15$ /group; two-way ANOVA, Groups: $\mathrm{F}(3,168)=84.74 \quad p<0.001$; Prepulse intensity: $F(2,168)=6.76 \quad p=0.001 ;$ Groups $\times$ Intensity: $\mathrm{F}(6,168)=1.99 \mathrm{NS}$; post hoc Bonferroni's test: apomorphine vs sal $p<0.001$ ), whereas rimonabant did not alter PPI (Figure 6a). As already shown for its effects on phencyclidine- or dizocilpine-disruption of PPI (see above), rimonabant significantly counteracted apomorphine-induced decrease of PPI (rimonabant + apomorphine $v s$ apomorphine 


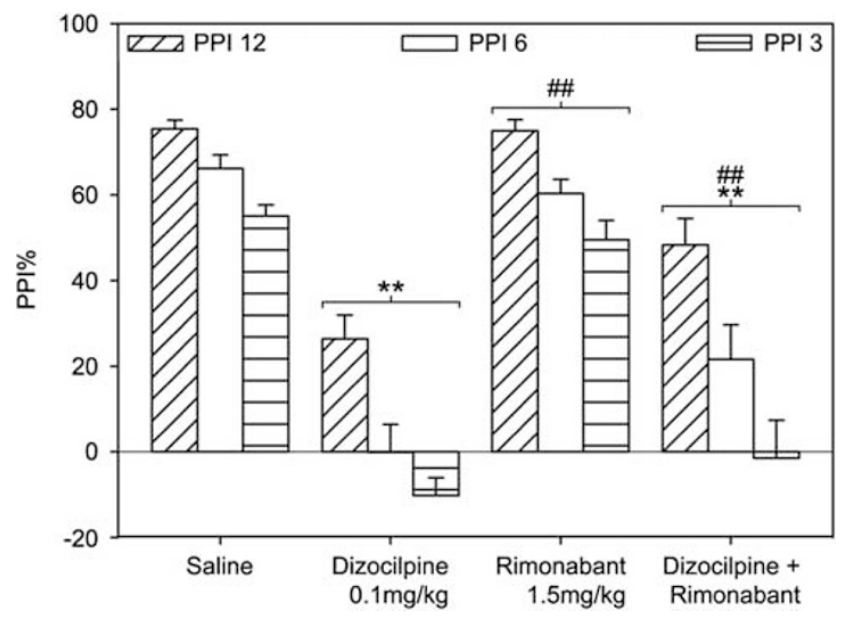

Figure 5 Effects of rimonabant ( $1.5 \mathrm{mg} / \mathrm{kg}$, s.c.) on PPI disruption induced by dizocilpine $(0.1 \mathrm{mg} / \mathrm{kg}$, s.c.).

$p<0.001$, rimonabant + apomorphine $v s$ sal $p<0.001$ ) (Figure 6a). No drug treatment significantly altered startle amplitude with respect to saline treatment (Figure 6b).

\section{DISCUSSION}

The main result of the present study is that the potent $\mathrm{CB}_{1}$ receptor antagonist rimonabant significantly counteracted PPI deficits induced by phencyclidine at all doses tested. Notably, the apparent lack of dose dependency for such an effect may likely reflect a dose range that omits lower, less effective doses of rimonabant in our experiments. To rule out the possibility that rimonabant might mediate these effects by engaging an as yet unidentified non- $\mathrm{CB}_{1}$ cannabinoid receptor (Breivogel et al, 2001), we also tested the highly specific $\mathrm{CB}_{1}$ antagonist AM251, obtaining similar results. Of note, both $\mathrm{CB}_{1}$ antagonists paralleled the ability of clozapine to antagonize the disruption of PPI induced by phencyclidine. Finally, rimonabant markedly reduced PPI deficits induced by dizocilpine, another NMDA antagonist, and apomorphine. No significant effects on startle magnitude were produced by any experiment. In sum, the results indicate that rimonabant exerts behavioral effects in pharmacological models of disrupted sensorimotor gating consistent with 'atypical' antipsychotic profile, and that these effects are mediated through blockade of the $\mathrm{CB}_{1}$ receptor. These findings are in agreement with previous evidence for antipsychotic-like properties of rimonabant, such as the ability to suppress the hyperactivity induced in gerbils by various psychotomimetic agents (Poncelet et al, 1999) and to attenuate memory impairments produced by $\Delta^{9}$-tetrahydrocannabinol (THC), the main psychoactive ingredient in cannabis, in rats (Mallet and Beninger, 1998).

Both rimonabant and AM251 are known to act as $\mathrm{CB}_{1}$ inverse agonists at relatively high doses (see, eg, Haller et al, 2004), raising the possibility that some of the observed results may not simply depend on $\mathrm{CB}_{1}$ blockade. Such a hypothesis seems to be ruled out by the significant effects elicited by lower doses of rimonabant $(0.75-1.5 \mathrm{mg} / \mathrm{kg}$, i.p.), at which this compound has been shown to exert no
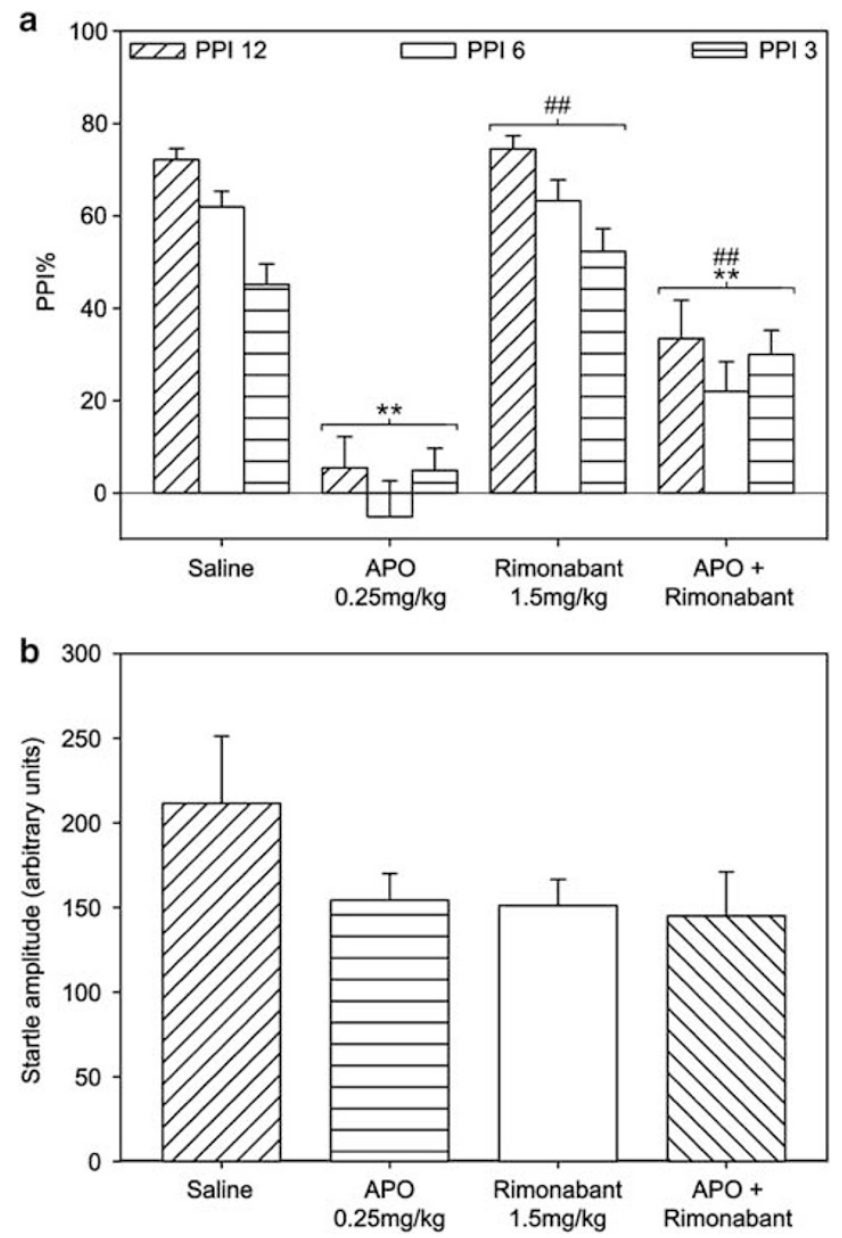

Figure 6 (a) Effects of rimonabant (1.5 mg/kg, s.c.) on PPI disruption induced by apomorphine $(0.25 \mathrm{mg} / \mathrm{kg}$, s.c.). (b) Effects of rimonabant ( $1.5 \mathrm{mg} / \mathrm{kg}$, s.c.) and $/$ or apomorphine $(0.25 \mathrm{mg} / \mathrm{kg}$, s.c.) on startle amplitude. $\mathrm{APO}=$ apomorphine.

intrinsic activity on $\mathrm{CB}_{1}$ receptors in rodent behavior (see, eg, Bortolato et al, 2006). Of note, such a possibility is also suggested by the lack of PPI effects induced by rimonabant per se in our study.

Part of our finding is in apparent contrast with a previous study by Martin et al (2003), who reported that rimonabant had no effect on PPI following disruption by dizocilpine, apomorphine and $d$-amphetamine. This discrepancy may be explained by the doses range used, the preparation of rimonabant, and the route of administration. Indeed, in our preliminary experiments we followed the experimental conditions of the study by Martin et al (2003) by administering rimonabant as a suspension of $0.5 \%$ carboxymethylcellulose via intraperitoneal injections. Under these experimental conditions inconsistent results were observed on the ability of rimonabant to reverse PPI disruption induced by NMDA antagonists and DA agonists (not shown). Although this might reflect a different influence of the route of administration on rat behaviors (Melzacka et al, 1979), we also considered the possibility that the vehicle used in that study was inadequate to fully dissolve rimonabant, owing to the highly lipophylic properties of the drug. Thus, we applied the recommendations of the 
National Institute of Mental Health Synthesis and Drug Supply Program including a high-impact study by DeVries et al (2001), who dissolved rimonabant in ethanol, Tween 80 and sterile saline (ratio $1: 1: 18$ ) and administered the drug s.c., in order to investigate the effects of the $\mathrm{CB}_{1}$ antagonist on the prevention of relapse to cocaine use. Following the protocol by deVries et al (2001), we were able to produce consistent and reproducible results.

In addition to differences in drug preparation, administration and dose range, differences in the parameters used for measurements of startle gating might also account for the discrepancy with the previous report. Martin et al (2003) used 5-, 11- and 17-dB prepulses over a background intensity of $68 \mathrm{~dB}$, whereas we used a more sensitive threshold range of PPI produced by prepulse intensities of 3-, 6-, and $12 \mathrm{~dB}$ above a background of $70 \mathrm{~dB}$. Previous studies have shown that deficits in PPI are most sensitively detected using weak prepulse stimuli rather than intense prepulse stimuli, thereby avoiding floor and ceiling effects (Swerdlow and Geyer, 1993). This observation merits further investigation and is in accordance with our results suggesting that PPI deficits in states of gating circuit dysfunction might be most sensitively detected in conditions in which the system can exhibit the greatest changes.

The NMDA receptor antagonist phencyclidine is frequently used to model schizophrenia in laboratory animals. This compound induces hyperlocomotion in the open field (Gleason and Shannon, 1997), hyperlocomotion and social deficit in the social withdrawal model (Corbett et al, 1995; Sams-Dodd, 1995), alters swimming patterns in the water maze (Ogawa et al, 1994; Okuyama et al, 1995), and increases immobility in the forced swimming test after chronic administration (Noda et al, 1995). Importantly, phencyclidine-induced disruption of PPI is a paradigm of sensorimotor gating abnormalities, which currently appear to be at the core of certain aspects of behavioral pathophysiology in the spectrum of schizophrenia-like disorders.

Although our findings suggest that the PPI-disruptive mechanisms of phencyclidine, dizocilpine, and apomorphine involve the activation of $\mathrm{CB}_{1}$ receptors, they do not allow to identify the neurobiological mechanisms underlying the antipsychotic-like actions of rimonabant. However, the ability of this drug to attenuate phencyclidine- and dizocilpine-mediated PPI disruptions - both absolutely insensitive to $\mathrm{D}_{2}$ receptor antagonists-suggests that rimonabant might exert its antipsychotic-like properties through nondopaminergic mechanisms. Several studies have reported that $\mathrm{CB}_{1}$ agonists can reduce glutamatergic synaptic transmission in several brain regions involved in the regulation of gating functions, such as the hippocampus (Fujiwara and Egashira, 2004; Misner and Sullivan, 1999), the prefrontal cortex (Auclair et al, 2000), the nucleus accumbens (Robbe et al, 2001) and the amygdala (Azad et al, 2003). Interestingly, the bulk of evidence identifies the endocannabinoid $2-\mathrm{AG}$ as the most probable retrograde mediator in long-term plasticity at glutamatergic synapses (Gerdeman et al, 2002; Robbe et al, 2002; Sjöström et al, 2003; Straiker and Mackie, 2005). In particular, 2-AG is synthesized in the postsynaptic terminal of glutamatergic synapses following activation of metabotropic mGLUR5 glutamate receptors (Jung et al, 2005) and is thought to transiently suppress glutamate release through activation of $\mathrm{CB}_{1}$ receptors located in presynaptic glutamatergic axon terminals (Katona et al, 2006). Notably, mGLUR5 receptors are known to modulate the psychotomimetic actions of NMDA receptor antagonists (Kinney et al, 2005) and their pharmacological or genetic impairment induces psychosislike behavior in animals (Brody et al, 2004; Kinney et al, 2003). In light of these premises, it is possible to speculate that inhibition of $\mathrm{CB}_{1}$ presynaptic receptors might limit the effects of 2-AG, thus enhancing glutamate release and neurotransmission on mGLUR5 and other glutamatergic postsynaptic receptors and limiting the PPI-disrupting impact of NMDA antagonists. Such a mechanism would also be in agreement with in vivo microdialysis studies indicating that THC inhibits the release of glutamate in the hippocampus and that this inhibition is antagonized by rimonabant (Fujiwara and Egashira, 2004). Thus, the behavioral effects of rimonabant that we observed could reflect inhibition of phencyclidine-induced decrease of glutamatergic neurotransmission.

A similar mechanism of action might also account for the ability of rimonabant to attenuate the deficit induced by apomorphine downstream the dopaminergic synapse. Changes in glutamatergic release are likely to affect the role of dopaminergic activation in PPI (Bortolato et al, 2005) and the positive modulation of glutamatergic transmission inhibits dopamine-mediated behaviors in the rats (Dall'Olio et al, 1994). Alternatively, rimonabant might reduce the apomorphine-mediated disruption through independent mechanisms, acting beyond the dopaminergic synapse. Further studies are warranted to better understand the role of CB1 receptors in apomorphine-mediated PPI disruption.

Apparently, our data are in contrast with previous literature highlighting an antipsychotic-like role of anandamide, the other CB1 receptor endogenous ligand (Beltramo et al, 2000; Giuffrida et al, 2004). Indeed, selective inhibition of anandamide degradation seems to have a protective role against the behavioral effects of $d$-amphetamine, including PPI disruption (Beltramo et al, 2000; Bortolato et al, in preparation). Preliminary studies suggest that anandamide may be implicated in the intrinsic regulation of dopamine release, by acting retrogradely on $\mathrm{CB}_{1}$ receptors located in a subset of dopaminergic presynaptic terminals to limit dopamine release. Interestingly, however, anandamide seems to have no effect on glutamate release. Under this perspective, it is possible to speculate that anandamide and 2-AG might subserve different physiological mechanisms and play different roles in the pathophysiology of schizophrenia, probably in parallel to the different mechanisms underlying psychosis. The intrinsic actions of rimonabant observed in this study might be plausibly consistent with a prevalent blockade of 2-AG actions. This effect is supported by observations attesting concentrations of 2-AG approximately 1000 times higher than anandamide in the brain (nanomolar $v s$ picomolar ranges per gram of brain tissue) (Bortolato et al, 2006; Hohmann et al, 2005).

The role of cannabinoid effects per se on PPI disruption is still a matter of debate. $\mathrm{CB}_{1}$ receptor agonists were shown to decrease startle amplitude, rendering PPI data difficult for interpretation (Mansbach et al, 1996; Martin et al, 2003). $\mathrm{CB}_{1}$ agonists were also reported to increase (Stanley-Cary 
et al, 2002) or to have no effects on PPI (Bortolato et al, 2004), whereas other two studies observed significant impairments of sensorimotor gating (Schneider and Koch, 2002, 2003). Discrepancies between results have been linked to differences in experimental design and/or strain diversity (Bortolato et al, 2004). Indeed, clinical data suggest that cannabis use appears to act as a risk factor in the onset of schizophrenia only in individuals who are vulnerable to psychosis, in ways that are still difficult to specify. Therefore, a PPI disruption model based on $\mathrm{CB}_{1}$ agonists in healthy animals might not capture some of the most relevant gating dysfunctions in schizophrenia, because the experimental subjects might not present any relevant aspects of vulnerability to psychosis. Accordingly, Malone and Taylor (2006) reported that THC produces significant PPI deficits in isolation-reared rats, which already exhibit dysfunctional sensorimotor gating, but not in normal rats. Moreover, genetic $\mathrm{CB}_{1}$ disruption in mice per se does not significantly affect behavior in the social withdrawal model, but highly counteracts the phencyclidine-induced social deficit, which is believed to model negative symptoms of schizophrenia (Haller et al, 2005). These results suggest that the relationship between cannabinoid signaling and schizophrenia might be best explored within an experimental context, where $\mathrm{CB}_{1}$ receptor involvement on the modulation of disturbed major neurotransmitter systems implied in schizophrenia can be investigated.

In the present study, we report that rimonabant and clozapine were equally effective in antagonizing the disruption of PPI produced by phencyclidine. As the PPIdisruptive effects of phencyclidine can be reversed by clozapine and other 'atypical', but not 'typical' antipsychotics in monkeys and rodents (Bakshi et al, 1994; Bakshi and Geyer, 1995; Geyer et al, 2001; Linn et al, 2003; Swerdlow et al, 1996), our findings may further strengthen the hypothesis that rimonabant may exhibit an 'atypical' antipsychotic profile. In addition, cotreatment of rimonabant and clozapine significantly reversed PPI deficits induced by phencyclidine, though no augmenting effect was observed, plausibly as both compounds proved fully efficacious in reversing phencyclidine-mediated PPI disruption. Cotreatment might represent a valuable therapeutic option warranting further investigation. Indeed, as rimonabant has been approved for human use as a novel antiobesity agent, it could perhaps counteract the considerable weight gain induced by clozapine.

Of note, the potent effects of rimonabant in the present investigation on NMDA-induced manipulation of sensorimotor gating were observed with a limited range of doses. This could explain why rimonabant failed to show improvement in global symptom severity or positive and negative symptoms in patients with schizophrenia when compared to placebo in the only published clinical trial to date (Meltzer et al, 2004). Other factors, such as the abovesuggested differential role of anandamide and 2-AG in psychotogenic mechanisms, as well as the heterogeneity of neurobiological mechanisms underlying psychotic disorders in humans, might contribute to explain the results of Meltzer et al.

In conclusion, our results show that rimonabant does mimic the abilities of clozapine to reverse NMDA-induced disruption of PPI. Given that the even more selective
$\mathrm{CB}_{1}$-antagonist $\mathrm{AM} 251$ was equally effective in restoring the phencyclidine-induced disruption of PPI, our findings suggest that these effects are mediated by the $\mathrm{CB}_{1}$ receptor. In the present study, rimonabant also counteracted the PPI disruptive effects in the animal model of deficient sensorimotor gating produced by apomorphine. Insofar as the phencyclidine-PPI model in rats appears to faithfully mimic some aspects of psychosis-related behavior, our findings recommend further interdisciplinary studies to better understand the relationship between glutamate transmission and the role of cannabinoid systems in the pathophysiology of schizophrenia. In addition, our findings recommend further clinical exploration of $\mathrm{CB}_{1}$ antagonists in selected subpopulations of schizophrenic patients.

\section{ACKNOWLEDGEMENTS}

This work has been supported in part by grants from the University of Brescia.

\section{REFERENCES}

Auclair N, Otani S, Soubrie P, Crepel F (2000). Cannabinoids modulate synaptic strength and plasticity at glutamatergic synapses. J Neurophysiol 83: 3287-3293.

Azad SC, Eder M, Marsicano G, Lutz B, Zieglgansberger W, Rammes G (2003). Activation of the cannabinoid receptor type 1 decreases glutamate and GABAergic synaptic transmission in the lateral amygdale of the mouse. Learn Memory 10: 116-128.

Bakshi VP, Geyer MA (1995). Antagonism of phencyclidineinduced deficits in prepulse inhibition by the putative atypical antipsychotic olanzapine. Psychopharmacology 122: 198-201.

Bakshi VP, Swerdlow NR, Geyer MA (1994). Clozapine antagonizes phencyclidine-induced deficits in sensorimotor gating of the startle response. J Pharmacol Exp Ther 27: 787-794.

Ballmaier M, Casamenti F, Scali C, Mazzoncini R, Zoli M, Pepeu G et al (2002). Rivastigmine antagonizes deficts in prepulse inhibition induced by selective immunolesioning of cholinergic neurons in nucleus basalis magnocellularis. Neuroscience 114: 91-98.

Ballmaier M, Zoli M, Mazzoncini R, Gennarelli M, Spano PF (2001). Combined $\alpha 2$-adrenergig/ $\mathrm{D}_{2}$ dopamine receptor blockade fails to reproduce the ability of clozapine to reverse phencyclidine-induced deficits in prepulse-inhibition of startle. Psychopharmacology 159: 105-110.

Beltramo M, de Fonseca FR, Navarro M, Calignano A, Gorriti MA, Grammatikopoulos G et al (2000). Reversal of dopamine D2 receptor responses by an anandamide transport inhibitor. J Neurosci 20: 3401-3407.

Bortolato M, Aru GN, Fa M, Frau R, Orru M, Salis P et al (2005). Activation of D1, but not D2 receptors potentiates dizocilpinemediated disruption of prepulse inhibition of the startle. Neuropsychopharmacology 30: 561-574.

Bortolato M, Aru GN, Frau R, Orrù M, Luckey GC, Boi G et al (2004). The CB receptor agonist WIN 55,212-2 fails to elicit disruption of prepulse inhibition of the startle in SpragueDawley rats. Psychopharmacology 177: 264-271.

Bortolato M, Campolongo P, Mangieri RA, Scattoni ML, Frau R, Trezza $\mathrm{V}$ et al (2006). Anxiolytic-like properties of the anandamide transport inhibitor AM404. Neuropsychopharmacology 31: 2652-2659.

Braff DL, Geyer MA, Swerdlow NR (2001). Human studies of prepulse inhibition of startle: normal subjects, patient groups, and pharmacological studies. Psychopharmacology 156: 117-154. 
Braff DL, Stone C, Callaway E, Geyer MA, Glick ID, Bali L (1978). Prestimulus effects on human startle reflex in normals and schizophrenics. Psychophysiology 15: 339-343.

Breivogel CS, Griffin G, Di Marzo V, Martin BR (2001). Evidence for a new $G$ protein-coupled cannabinoid receptor in mouse brain. Mol Pharmacol 60: 155-163.

Brody SA, Dulawa SC, Conquet F, Geyer MA (2004). Assessment of a prepulse inhibition deficit in a mutant mouse lacking mGLU5 receptors. Mol Psychiatry 9: 35-41.

Corbett R, Camacho F, Woods AT, Kerman LL, Fishkin RJ, Brooks $\mathrm{K}$ (1995). Antipsychotic agents antagonize non-competitive $\mathrm{N}$-methyl-D-aspartate antagonist-induced behaviours. Psychopharmacology 120: 67-74.

Dall'Olio R, Rimondini R, Gandolfi O (1994). The NMDA positive modulator D-cycloserine inhibits dopamine-mediated behaviors in the rat. Neuropharmacology 33: 55-59.

Dean B, Sundram S, Bradburgy R, Scarr E, Copolov D (2001). Studies on $\left[{ }^{3} \mathrm{H}\right] \mathrm{CP}-55940$ binding in the human central nervous system: regional specific changes in density of cannabinoid-1 receptors associated with schizophrenia and cannabis abuse. Neuroscience 103: 9-15.

De Vries TJ, Shaham Y, Homberg JR, Crombag H, Schuurman K, Dieben J et al (2001). A cannabinoid mechanism in relapse to cocaine seeking. Nat Med 10: 1151-1154.

Dixon L, Haas G, Weiden PJ, Sweeney J, Frances AJ (1991). Drug abuse in schizophrenic patients: clinical correlates and reasons for use. Am J Psychiatry 148: 224-230.

Domenici MR, Azad SC, Marsicano G, Schierloh A, Wotjak CT, Dodt $\mathrm{H}$ et al (2006). Cannabinoid receptor type I located on presynaptic terminals of principal neurons in the forebrain controls glutamatergic synaptic transmission. J Neurosci 26: 5794-5799.

Fujiwara M, Egashira N (2004). New perspectives in the studies on endocannabinoid and cannabis: abnormal behaviours associate with $\mathrm{CB}_{1}$ cannabinoid receptor and development of therapeutic application. J Pharmacol Sci 96: 362-366.

Gerdeman GL, Ronesi J, Lovinger DM (2002). Postsynaptic endocannabinoid release is critical to long-term depression in the striatum. Nat Neurosci 5: 446-451.

Geyer MA, Ellenbroek B (2003). Animal behavior models of the mechanisms underlying antipsychotic atypicality. Prog NeuroPsychopharmacol Biol Psychiatry 27: 1071-1079.

Geyer MA, Krebs-Thompson K, Braff DL, Swerdlow NR (2001). Pharmacological studies of prepulse inhibition models of sensorimotor gating deficits in schizophrenia: a decade of review. Psychopharmacology 156: 117-154.

Giuffrida A, Leweke FM, Gerth CW, Schreiber D, Koethe D, Faulhaber J et al (2004). Cerebrospinal anadamide levels are elevated in acute-schizophrenia and are inversely correlated with psychotic symptoms. Neuropsychopharmacology 29: 2108-2114.

Gleason SD, Shannon HE (1997). Blockade of phencyclidineinduced hyperlocomotion by olanzapine, clozapine and serotonin receptor subtype selective antagonists in mice. Psychopharmacology 129: 79-84.

Gotesman I, Gold T (2003). The endophenotype concept in psychiatry: etymology and strategic intentions. Am J Psychiatry 160: 636-645.

Hajos N, Freund TF (2002). Pharmacological separation of cannabinoid sensitive receptors on hippocampal excitatory fibers and inhibitory fibers. Neuropharmacology 43: 503-510.

Hall W (1998). Cannabis use and psychosis. Drug Alcohol Rev 17: 433-444.

Hall W (2006). Is cannabis use psychotogenic? Lancet 367: 193-195.

Haller J, Varqa B, Ledent C, Freund TF (2004). CB1 cannabinoid receptors mediate anxlolytic effects: convergent genetic and pharmacological evidence with CB1-specific agents. Behav Pharmacol 15: 299-304.
Haller J, Szirmai M, Varga B, Ledent C, Freund TF (2005). Cannabinoid $\mathrm{CB} 1$ receptor dependent effects of the NMDA antagonist phencyclidine in the social withdrawal model of schizophrenia. Behav Parmacol 16: 415-422.

Heinz A, Romero B, Gallinat J, Juckel G, Weinberger DR (2003). Molecular brain imaging and the neurobiology and genetics of schizophrenia. Pharmacopsychiatry 36: S152-S157.

Henquet C, Krabbendam L, Spauven J, Kaplan C, Lieb R, Wittchen HU et al (2005). Prospective cohort study of cannabis use, predisposition for psychosis, and psychotic symptoms in young people. BMJ 330: 11 .

Heresco-Levy U (2005). Glutamatergic neurotransmission modulators as emerging new drugs for schizophrenia. Expert Opin Emerg Drugs 10: 827-844.

Hohmann AG, Suplita RL, Bolton NM, Neely MH, Fegley D, Mangieri $\mathrm{R}$ et al (2005). An endocannabinoid mechanism for stress-induced analgesia. Nature 435: 1108-1112.

Jablensky A, Sartorius N, Ernberg G, Anker M, Korten A, Cooper JE et al (1992). Schizophrenia: manifestations, incidence and course in different cultures. A World Health Organizationcountry study. Psychol Med Monogr 20(Suppl): 1-97.

Jung KM, Mangieri R, Stapleton C, Kim J, Fegley D, Wallace M et al (2005). Stimulation of endocannabinoid formation in brain slice cultures through activation of group I metabotropic glutamate receptors. Mol Pharmacol 68: 1196-1202.

Katona I, Urban GM, Wallace M, Ledent C, Jung K, Piomelli D et al (2006). Molecular composition of the endocannabinoid system at glutamatergic synapses. J Neurosci 26: 5628-5637.

Keith V, Mansbach RS, Geyer MA (1991). Failure of haloperidol to block the effects of phencyclidine and dizocilpine on prepulse inhibition of startle. Biol Psychiatry 30: 557-577.

Kinney GG, Bruno M, Campbell UC, Hernandez LM, Rodriguez D, Bristow LJ et al (2003). Metabotropic glutamate subtype 5 receptors modulate locomotor activity and sensorimotor gating in rodents. J Pharmacol Exp Ther 306: 116-123.

Kinney GG, O’Brien JA, Lemaire W, Burno M, Bickel DJ, Clements MK et al (2005). A novel selective positive allosteric modulator of metabotropic glutamate receptor subtype 5 has in vivo activity and antipsychotic-like effects in rat behavioural models. J Pharmacol Exp Ther 313: 199-206.

Krystal JH, D’Souza DC, Madonick S, Petrakis IL (1999). Toward a rational pharmacotherapy of comorbid substance abuse in schizophrenic patients. Schizophr Res 35: S35-S49.

Linn GS, Negi SS, Gerum SV, Javitt DC (2003). Reversal of phencyclidine-induced prepulse inhibition deficits by clozapine in monkeys. Psychopharmacology 169: 234-239.

Mallet PE, Beninger RJ (1998). The cannabinoid CB1 receptor antagonist SR141716A attenuates the memory impairment produced by delta9-tetrahydrocannabinol or anandamide. Psychopharmacology 140: 11-19.

Malone DT, Taylor DA (2006). The effect of Delta9-tetrahydrocannabinol on sensorimotor gating in socially isolated rats. Behav Brain Res 166: 101-109.

Mansbach RS, Geyer MA (1989). Effects of phencyclidine and phencyclidine biologs on sensorimotor gating in the rat. Neuropsychopharmacology 2: 299-308.

Mansbach RS, Rovetti CC, Winston EN, Lowe III JA (1996). Effects of the cannabinoid CB1 receptor antagonist SR141716A on the bevavior of pigeons and rats. Psychopharmacology 124: 315-322.

Martin RS, Secchi RL, Sung E, Lemaire M, Bonhaus DW, Hedley LR et al (2003). Effects of cannabinoid receptor ligands on psychosis-relevant behavior models in rats. Psychopharmacology 165: 128-135.

Martinez ZA, Platten A, Polack E, Shoemaker J, Ro H, Pitcher L et al (2002). Typical but not 'atypical' antipsychotic effects on startle gating deficits in prepubertal rats. Psychopharmacology 161: $38-46$. 
Mato S, Pazos A, Valdizàn EM (2002). Cannabinoid receptor antagonism and inverse agonism in response to SR141716A on cAMP production in human and rat brain. Eur J Pharmacol 443: 43-46.

McGhie A, Chapman J (1961). Disorders of attention and perception in early schizophrenia. Br J Med Psychol 34: 103-116.

Meltzer HY, Arvanitis L, Bauer D, Rein W (2004). Placebocontrolled evaluation of four novel compounds for the treatment of schizophrenia and schizoaffective disorder. Am J Psychiatry 161: 975-984.

Melzacka M, Wiszniowska G, Daniel W, Vetulani J (1979). Behavioral effects and cerebral pharmacokinetics of apomorphine in the rat: dependence upon the route of administration. Pol J Pharmacol Pharm 31: 309-317.

Misner DL, Sullivan JM (1999). Mechanism of cannabinoid effects on long-term potentiation and depression in hippocampal CA1 neurons. J Neurosci 19: 6795-6805.

Moghaddam B, Jackson ME (2003). Glutamatergic animal models of schizophrenia. Ann NY Acad Sci 1003: 131-137.

Noda Y, Yamada K, Furukawa H, Nabeshima T (1995). Enhancement of immobility in a forced swimming test by subacute or repeated treatment with phencyclidine: a new model of schizophrenia. Br J Pharmacol 116: 1537-2531.

Ogawa S, Okuyama S, Araki H, Nakazato A, Otomo S (1994). A rat model of phencyclidine psychosis. Life Sci 55: 1605-1610.

Okuyama S, Ogawa S, Nakazato A, Tomizawa K (1995). Effect of NE-100, a novel sigma receptor ligand, on phencyclidineinduced delayed cognitive dysfunction in rats. Neurosci Lett 189: 60-62.

Piomelli D (2003). The molecular logic of endocannabinoid signaling. Nat Rev Neurosci 4: 873-884.

Poncelet M, Barnouin MC, Brelière JC, Le Fur G, Soubrié P (1999). Blockade of cannabinoid (CB1) receptors by SR141716A selectively antagonizes drug-induced reinstatement of exploratory behaviour in gerbils. Psychopharmacology 144: 144-150.

Rinaldi-Carmona M, Calandra B, Shire D, Bouaboula M, Oustric D, Barth F et al (1996). Characterization of two cloned human CB1 cannabinoid receptor isoforms. J Pharmacol Exp Ther 278: 871-878.

Robbe D, Alonso G, Duchamp F, Bockaert J, Manzonl OJ (2001). Localization and mechanisms of action of cannabinoid receptors at the glutamatergic synapses of the mouse nucleus accumbens. J Neurosci 21: 109-116.

Robbe D, Kopf M, Remaury A, Bockaet J, Manzoni OJ (2002). Endogenous cannabinoids mediate long-term synaptic depression in the nucleus accumbens. Proc Natl Acad Sci USA 99: $8384-8388$.

Sams-Dodd F (1995). Distinct effects of $d$-amphetamine and phencyclidine on the social behaviour of rats. Behav Pharmacol 6: 55-65.

Schneider M, Koch M (2002). The cannabinoid agonist WIN $55,212-2$ reduces sensorimotor gating and recognition memory in rats. Behav Pharmacol 13: 29-37.

Schneider M, Koch M (2003). Chronic pubertal, but not adult chronic cannabinoid treatment impairs sensorimotor gating, recognition memory, and the performance in a progressive ratio task in adult rats. Neuropsychopharmacology 28: $1760-1769$

Semple DM, McIntosh AM, Lawrie SM (2005). Cannabis use as a risk factor for psychosis: systematic review. J Psychopharmacology 19: 187-194.

Sjöström PJ, Turrigiano GG, Nelson SB (2003). Neocortical LTD via coincident activation of presynpatic NMDA and cannabinoid receptors. Neuron 39: 641-654.

Stanley-Cary CC, Harris C, Martin-Iverson MT (2002). Differing effects of the cannabinoid agonist CP 55,940, in an alcohol or Tween 80 solvent, on prepulse inhibition of the acoustic startle reflex in the rat. Behav Pharmacol 13: 15-28.

Straiker A, Mackie K (2005). Depolarization-induced suppression of excitation in murine autaptic hippocampal neurones. J Physiol 569: 501-517.

Swerdlow NR, Geyer MA (1993). Clozapine and haloperidol in an animal model of sensorimotor gating deficits in schizophrenia. Pharmacol Biochem Behav 44: 741-744.

Swerdlow NR, Bakshi V, Geyer MA (1996). Seroquel restores sensorimotor gating in phencyclidine-treated rats. J Pharmacol Exp Ther 279: 1290-1299.

Swerdlow NR, Geyer MA (1998). Using an animal model of deficient sensorimotor gating to study the pathophysiology and new treatments. Schizophr Bull 24: 285-301.

Swerdlow NR, Martinez ZA, Hanlon FM, Platten A, Farid M, Auerbach P et al (2002). Toward understanding the biology of a complex phenotype: rat strain and substrain differences in the sensorimotor gating-disruptive effects of dopamine agonists. J Neurosci 20: 4325-4336.

Tzavara ET, Li DL, Moutsimilli L, Bisogno T, DiMarzo V, Phebus LA et al (2006). Endocannabinoids activate transient receptor potential vanilloid 1 receptors to reduce hyperdomainergiarelated hyperactivity: therapeutic implications. Biol Psychiatry 59: 508-515.

Ujike H, Morita Y (2004). New perspectives in the studies on endocannabinoid and cannabis: cannabinoid receptors and schizophrenia. J Pharmacol Sci 96: 376-381.

Ujike H, Takaki M, Nakata K, Tanaka Y, Takeda T, Kodama M et al (2002). CNR1, central cannabinoid receptor gene, associated with susceptibility to hebephrenic schizophrenia. Mol Psychiatry 7: 515-518.

Van der Stelt M, Di Marzo V (2003). The endocannabinoid system in the basal gamglia and in the mesolimbc reward system. Implications for neurological and psychiatric disorders. Eur $J$ Pharmacol 480: 133-150.

Zavitsanou K, Garrick T, Huang XF (2004). Selective antagonist [3H]SR141716A binding to cannabinoid CB1 receptors is increased in the anterior cingolate in schizophrenia. Prog Neuropsychopharmacol Biol Psychiatry 28: 355-360.

Zhang J, Pouzet B, Jongen-Relo AL, Weiner I, Feldon J (1999). Disruption of prepulse inhibition following $N$-methyl-D-aspartate infusion into the hippocampus is antagonized by clozapine but not by haloperidol: a possible model for the screening of atypical antipsychotics. Neuroreport 10: 2533-2538. 